\title{
VAGINAL EVISCERATION AFTER ABDOMINAL HYSTERECTOMY
}

\author{
Evrim ERDEMOGLU, Ilker GUNYELI, Mehmet GUNEY, Hilmi Baha ORAL, Gokhan BAYHAN,Tamer MUNGAN
}

Department of Gynecology and Obstetric, Faculty of Medicine, Suleyman Demirel University, Isparta, Turkey

\begin{abstract}
SUMMARY
Objective: Vaginal evisceration is rarely encountered. Aim of the present study is to report an uncommon case of vaginal evisceration after abdominal hysterectomy in a premenopausal woman without enterocele. Literature is reviewed to study and discuss the predisposing risk factors and management of vaginal evisceration.

Case: A 53 years-old, premenopausal patient was admitted to the hospital with vaginal evisceration at the postoperative fourth day after hysterectomy (where cuff was left open). Ileum was prolapsed thorough the vagina where it was reduced by emergency laparotomy. Additional culdoplasty was performed to obliterate Douglas pouch. On her previous medical history, she had recurrent rectal prolapse and surgeries for this disorder. Literature was reviewed and discussed along with this case in order to identify risk factors of vaginal evisceration. This information may lead to change of hysterectomy technique in selected patients.

Conclusions: Diabetes, early coitus, use of steroid, pelvic prolapse, trauma and chronic obstructive respiratory disease are risk factors for vaginal evisceration. Vaginal evisceration shoud be considered during the hysterectomy and postoperative follow up of these patients. Association of rectal prolapse and vaginal evisceration is not reported and this is the first study reporting a relation between rectal prolapse and vaginal evisceration. In our case report, rectal prolaps and previous rectal surgery was a risk factor for vaginal evisceration. Reinforcement of vaginal cuff by culdoplasty and obliteration of vaginal cuff is adviced in these cases.
\end{abstract}

Key words: hysterectomy, rectal prolapse, vaginal evisceration

Journal of Turkish Society of Obstetrics and Gynecology, (J Turk Soc Obstet Gynecol), 2011; Vol: 8 Issue: 2 Pages: 149- 52

\section{ABDOMINAL HISTEREKTOMI SONRASI VAJINAL EVISERASYON}

\section{ÖZET}

Amaç: Vajinal eviserasyon çok nadir görülen önemli bir durumdur. Vaka sunumunun amacı premenopozal enteroseli olmayan bir kadında abdominal histerektomi sonrasında bu çok nadir görülen komplikasyonun bildirilmesidir. Histerektomi sonrasi vajinal eviserasyon olgusunun bildirilmesi ve literatür bilgileri doğrultusunda histerektomi tekniğinde vajinal kafin açık bırakılması açısından riskli olan hastaların araştırılmasıdır.

Olgu: Elli üç yaşında, premenopozal bir kadın hastada vajinal kafin açık bırakıldığı abdominal histerektomi sonrasında postoperatif dördüncü gününde vajinal eviserasyonla başvurdu. Fizik muayenede ileumun vajenden dişarı herniye olduğu tespit edilen hasta acil laparotomiye alınarak redüksiyon yapıldı ve kuldoplasti uygulandl. Özgeçmişinde tekrarlayan rektal prolapsusu bulunan hastanın risk faktörleri literatürle birlikte değerlendirilip, vajinal kafin sütüre edilmesi gereken özel olguların neler olabileceği tartışıldı.

Sonuç: Diabet, erken koitus, steroid kullanımı, pelvik prolapsus, travma, kronik obstrüktif akciğer hastalıkları da risk faktörü olabileceğinden bu hastaların histerektomisinde ve takiplerinde vajinal eviserasyon olabileceği düşünülmelidir.

Address for Correspondence: Evrim Erdemoglu. Süleyman Demirel Üniversitesi Tıp Fakültesi, Kadın Hastalıkları ve Doğum Anabilim Dalı, Isparta, Turkey Phone: +90 (505) 2724344

e-mail: evrimmd@yahoo.com

Received: 25 February 2010, revised: 07 May 2010, accepted: 21 June 2010, online publication: 14 March 2011 
Günümüze kadar muhtemel rektal prolapsın vajinal eviserasyonla ilişkisi bildirilmemiş olup bu literatürde bildirilmiş ilk vakadır. Bizim olgumuzda literatürden farklı olarak rektal prolapsus, geçirilmiş rektal cerrahi ek risk faktörü olup, bu durumlarda vajinal kafin oblitere edilip kuldoplasti ile güçlendirilmesi vajinal eviserasyonun önlenmesi için önerilebilir.

Anahtar kelimeler: histerektomi, rektal prolaps, vajinal eviserasyon

Türk Jinekoloji ve Obstetrik Derneği Dergisi, (J Turk Soc Obstet Gynecol), 2011; Cilt: 8 Sayl: 2 Sayfa: 149- 52

\section{INTRODUCTION}

Vaginal evisceration is a rarely encountered, important situation $^{(1)}$. There has been about a hundred cases in the literature, which usually occured after vaginal hysterectomy in postmenopausal women with enterocel $^{(2,3)}$. Although the incidence of hysterectomy is high, vaginal evisceration is a seldomly encountered complication, and the management after vaginal evisceration is not clear. Aim of the study is to report an unsual complication of abdominal hysterectomy, vaginal evisceration in a premenopausal women without enterocel, and to discuss and study the predisposing risk factors in our case and literature.

\section{CASE REPORT}

A 53 years old, gravida 4, STRAW (stages of reproductive aging workshop) -1 women with menometroragia was admitted to the department of Obstetrics and Gynecology, suleyman Demirel University in october 2008. In her past medical history, she had asthma. Her body mass index was 30 . In her past gynecological history, she had vaginal deliveries, ovarian cystectomy, colporaphy anterior, abdominal hernia, and she was operated 3 times for recurrent rectal prolapse. She had her first rectal prolapse operation in 1993 along with colporaphy anterior, rectopexy and ovarian cystectomy. In 2006, she had Delorme operation (excision and plication of rectal mucosa after freeing from anal sphincter via transperineal approach) and posterior colporaphy for recurrent rectal prolapse. She had another reccurence of rectal prolapse in 2007. Reccurecne was managed by Notaras operation in which rectum was stabilized to sacrum with a mesh via laparotomy. Four months after this operation, she had a hernia in the median laparotomy incision site which was repaired by prolene mesh.

In her gynecological examination, the blades of the speculum was rotated for 180 degrees. There was no peristaltism of small bowel and bulging in the posterior vaginal wall. Absence of enterocel was confirmed by rectovaginal examination in the standing position of patient. An adnexal mass of $5 \times 6 \mathrm{~cm}$ was found in the examination. Ultrasonography revealed normal uterine findings, and a semisolid ovarian mass of 50x50mm in the left adnexa and 60x60mm multiloculated, septated cystic mass in the right adnexa. There was no remarkable finding in her laboratory tests. The patient was undertaken to total abdominal hysterectomy and bilateral salpingoopherectomy. The vaginal cuff was left opened, by a circular suture on the incisional edges of the cuff. Frozen examination of the specimen was reported to be benign. Abdominal fascia was sutured with a PDS no 1 . The patient had no postoperative complication and she was discharged on postoperative third day. Urgently, she returned to the clinic one day after her discharge with vaginal evisceration. Her vital signs were stabile. Bowel loops were found to herniated through the vaginal cuff outside the vagina. The bowel loops were viable with normal peristaltism and there was no color change indicatin ischemia. Incisional hernia was also found in the umbilicus. Herniated bowel loops were washed with serum physiologic and covered with steril pads. Prophylactic antibiotics were admistered to the patient and she was taken to the laparotomy with a low median incision 30 minutes after evisceration. Terminal ileum and distal ileum was filling the pelvic cavity and small bowel loops were herniated through the constricting vaginal cuff. There was edema in the bowel loops. Hernia of bowel loops were reducted and the vaginal cuff was sutured with polyglactin no 1 . Halban culdoplasty was undertaken to obliterate the pouch of Douglas. In order to repair the incisional hernia in the abdominal wall, rectal fasia was dissected laterally and the tension in the rectal fascia was released by longitudinal incision in the fascia. The defect was sutured by PDS no1. There was no complication in the postoperative period and her follow up in the first and third month after operation. 


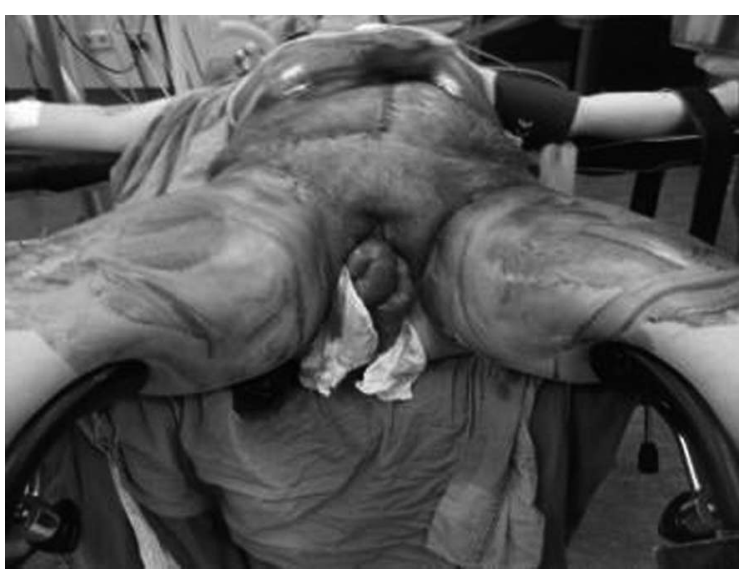

Picture I: Evisceration of the ileum anses after abdominal hysterectomy is a rarely seen complication.

\section{DISCUSSION}

In this case report, we have presented a ileal evisceration through a vaginal cuff which sutured circumferentially and left open after abdominal hysterectomy. There has been no report studying the relation of vaginal evisceration and rectal prolapse until today. Ther has been about 100 reported cases until $1846^{(5)}$. Most of these cases were postmenopausal. Besides, these cases usually had enterocel, vaginal surgery and pelvic prolapse. Increased intra-abdominal pressure and vaginal atrophy with distended enterocel is thought to be a predisposing factor. In premenopausal women, coitus, obstetrical trauma and foreign material may cause evisceration. The etiology and risk factors for vaginal evisceration is not clear due to limited reports in the literature. However, poor surgical technique resulting in weakness of vaginal apex, hematoma in the cuff, abscess, coitus before wound healing, use of steroids, malnutrion, diabetes are reported as risk factors $(5,6)$.

Sharvanahalli et al reported a case of vaginal evisceration which occurred during coitus three months after total abdominal hysterectomy in a 39 years old woman. Timing and frequency of coitus should be long and low, respectively after the operation. The coitus should be undertaken after assuring the vaginal cuff wound healing is complete. This approach may reduce the risk of vaginal evisceration.

These risk factors were not present in our case. The only apparent risk factor was presence of asthma which caused increased intraabdominal pressure. However, she was receiving broncodilator medications and she had no attack after the operation. The presence of reccurent rectal prolapse may be an risk factor for vaginal evisceration. Deep pousch of Douglas, atony of pelvic floor and anal sphincter muscles, loss of function of internal anal sphincter and external anal sphincter due to impaired pudendal nerve innervation, and impaired rectal fixation are reported to be risk factors for development of rectal prolapse ${ }^{(8,9)}$. Besides, small bowel loops in front of the prolapsed rectum forces the rectal mucosa out of the anus ${ }^{(8,9)}$. These risk factors for rectal prolapse may also be predisposing for vaginal evisceration. The previous rectopexy operation may result in a change in the axis of rectum in the pelvis. This may facilate the evisceration of bowel through the vagina. Besides, previous rectal operations may cause damage in the pelvic plexus. This causes constipation and increased intraabdominal pressure which may force the bowel out of the vaginal cuff.

The type of hysterectomy may be an additional risk factor for vaginal evisceration. Vaginal evisceration is usually encountered after vaginal or laparoscopic hysterectomy, and seldomly after abdominal hysterectomy ${ }^{(10)}$. Vaginal cuff is preferred to be left open in order to drain debris, blood clots and to reduce complications in the vaginal cuff(11). De laco et al reported that there is no relation between obliteration of vaginal cuff and vaginal evisceration.

The most common organ prolapsing through the vaginal cuff is ileum, however, omentum, fallopian tube and appendiks may also eviscerate. Ramin et al reported that the fallopian tubes were the most common herniating $\operatorname{organ}^{(12)}$. The eviscerated organ can be reduced by vaginal, laparoscopic or laparotomic approach. We have preferred abdominal approach as it was possible to expose the viability of herniated organs proximally along with abdominal exploration. Abdominal or laparoscopic approach is also beneficial as they provide identification and correction of predisposing risk factors for vaginal evisceration.

In conclusion, vaginal evisceration is a very rare complication which does not mandate suture reinforcement of vaginal cuff in every case. Establishment of predisposing factors may be possible as the vaginal evisceration cases are reported. Identifiaction of risk factors may contribute to the selection of cases and will prevent the vaginal evisceration. In contrast to literature, we identified 
rectal prolapse and previous rectal surgery as an additional to risk factor. Oblietration of cuff and suture reinforcement may prevent vaginal evisceration in these selected cases. However, the recurrent rectoceles in our patient may also be incidental. Diabetes, early coitus after operation, use of steroids, pelvic prolapse, trauma, chronic obstructive lung diseases are risk factors for vaginal evisceration. Surgeon should approach to these women keeping in mind that vaginal evisceration may occur.

\section{REFERENCES}

1. Partsinevelos GA, Rodolakis A, Athanasiou S, Antsaklis A Vaginal evisceration after hysterectomy: a rare condition a gynecologist should be familiar with. Arch Gynecol Obstet 2008; 29: [Epub ahead of print].

2. Yüce K, Dursun P, Gültekin M. Posthysterectomy intestina prolapse after coitus and vaginal repair. Arch Gynecol Obstet 2005; 272(1): 80- 1 .

3. Ramirez PT, Klemer DP. Vaginal evisceration after hysterectomy a literature review. Obstet Gynecol Surv 2002; 57: 462- 7 .

4. Notaras MJ. The use of Mersilene mesh in rectal prolapse repair. Proc R Soc Med. 1973; 66: 684- 6.

5. Rajesh S, Kalu E, Bong J, Wales N. Evisceration 5 years post abdominal hysterectomy. J Obstet Gynaecol Res. 2008; 34(3): 425- 7 .

6. Ramirez PT, Klemer DP. Vaginal evisceration after hysterectomy: a literature review. Obstet Gynecol Surv. 2002; 57(7): 462- 7.

7. Shravanahalli S, Nallapeta S, Ahmed A, Edi-Osagie EC. Should we consent for bowel evisceration as a potential complication of hysterectomy? J Obstet Gynaecol. 2008; 28(4): 455.

8. Kuijpers HC. Treatment of complete rectal prolapse: to narrow, to wrap, to suspend, to fix, to encircle, to plicate or to resect? World J Surg. 1992; 16: 826- 30.

9. Madiba TE, Baig MK, Wexner SD. Surgical management of rectal prolapse. Arch Surg. 2005; 140(1): 63- 73

10. Iaco PD, Ceccaroni M, Alboni C, Roset B, Sansovini M, D'Alessandro L, Pignotti E, Aloysio DD. Transvaginal evisceration after hysterectomy: is vaginal cuff closure associated with a reduced risk? Eur J Obstet Gynecol Reprod Biol. 2006; 125(1): 134- 8 .

11. R.S. Kirsner and W.H. Edglstein, The wound healing process, Dermatol Clin 1993; 11: 629-40.

12. Ramin SM, Ramin KD, Hemsell DL. Fallopian tube prolapse after hysterectomy. South Med J. 1999; 92(10): 963- 